\title{
РОЛЬ ВОЛОНТЕРСЬКОЇ ДІЯЛЬНОСТІ В ПОДОЛАННІ ДЕПРЕСИВНИХ СТАНІВ У ПАЦІЕНТІВ ХОСПІСУ
}

\author{
Н. Ю. Струбіцька
}

Луцький базовий медичний коледж

У статті досліджено рівень депресії в пацієнтів хоспісу та діяльність волонтерів при наявності депресивних станів у паліативних пацієнтів.

\section{THE ROLE OF VOLUNTEER ACTIVITY IN RELIEVING HOSPICE PATIENTS DEPRESSIVE CONDITIONS}

\author{
N. Y. Strubitska
}

Lutsk Base Medical College

The article deals with the investigation of Hospice patient' depression level and volunteer's activity in the presence of palliatave patients who suffer from depressive conditions.

Вступ. Волонтерський рух є актуальною складовою паліативної та хоспісної допомоги. Волонтерство $є$ одним із важливих компонентів паліативної медицини як галузі наукової медицини та охорони здоров'я. Практика роботи 3 добровольцями не отримала поки що належного поширення у суспільстві. Спостерігається дефіцит волонтерських кадрів у сфері паліативної та хоспісної допомоги. Для активізації розвитку волонтерства у системі паліативної допомоги можливе залучення до роботи у хоспісах студентів медичного коледжу, майбутніх медичних працівників. Адже студенти на випускному курсі вже мають достатні знання та вміння і можуть здійснювати кваліфікований догляд та опіку. У свою чергу, контроль досвідчених медичних працівників хоспісу стимулюватиме волонтерів до виявлення максимального професійного потенціалу в роботі з пацієнтами.

Співпраця майбутніх медиків із мультидисциплінарною командою хоспісу забезпечує не лише професійне становлення студентів як професіоналів своєї справи, а й задовольняе фізичні, соціальні, психологічні та духовні потреби пацієнтів хоспісу. Це дає можливість забезпечити належну якість життя паліативним пацієнтам.

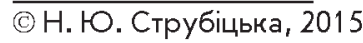

Волонтеру необхідно володіти інформацією про психоемоційний стан пацієнта, адже паліативна допомога - це складна, активна, комплексна допомога невиліковно хворій людині, яка охоплюе пацієнтів, сім'ю та громаду, має за мету збереження найвищої якості життя паціента. Усвідомлення пацієнтом власної тяжкої хвороби, несприятливий перебіг захворювання із загрозою для життя пацієнта, викликає розвиток нозогенної депресії [1]. Важливе значення має самопочуття хворого. Волонтери можуть виявити психологічні проблеми паціента, зокрема депресивні стани, через спостереження за пацієнтом, бесіду, фізичне обстеження, збір та аналіз суб'єктивних та об'єктивних даних.

Депресія - це стан зниженого настрою з домінуванням емоцій астенічного полюса (апатія, тривога, страх, смуток). Депресивний стан вважають патологічним тоді, коли не виявлено його специфічної психологічної причини або коли сам стан триває надто довго і його симптоми $е$ тяжкими. Розглядати депресію як хворобу можливо лише в тому випадку, коли зміна настрою відносно фіксована, є стійкою протягом 2-х і більше тижнів та позначається на поведінці, мисленні, діяльності всього організму.

Існуе соматогенна депресія, пов'язана 3 хворобливими відчуттями через соматичне захво- 
рювання, яке є безпосередньою причиною депресії, прискорюе розвиток депресії при наявності відповідної схильності [2]. Депресія може розвинутися як реакція на тяжке соматичне захворювання, яке зумовлене низкою психологічних, соціальних, особистісних, біологічних факторів, що містять об'єктивні параметри порушення рівня здоров'я. Посилюе депресію фізичний дискомфорт: біль, обмеження рухової активності, дефіцит самодогляду тощо.

Метою даного дослідження було виявити напрямки покращення підготовки студентів медичного коледжу до майбутньої волонтерської діяльності, зокрема у хоспісі, через вивчення особливостей психологічного стану паціентів, які уже отримують волонтерський догляд.

Студенти-волонтери здійснили всебічну оцінку стану паціента та застосували холістичний підхід щодо надання медичної та психологічної допомоги. Під керівництвом викладача, з метою визначення депресивних станів і станів, близьких до депресії, було застосовано опитувальник Зунге (в адаптації Т. І. Балашової) [3]. На базі Волинської лікарні «Хоспіс» обстежено 20 паціентів.
Відбір пацієнтів здійснювали за рівнем функціональних можливостей до спілкування.

Основна частина. Студенти IV курсу спеціальності «Сестринська справа» Луцького базового медичного коледжу регулярно здійснюють волонтерську діяльність у Волинській обласній лікарні «хоспіс». Окрім, відповідної фахової підготовки, дотримання вимог професійної етики, волонтери мають відповідні знання медичної психології. Навички психологічного спостереження дозволяють студентам-медикам вивчати психічні процеси, фізіологічні та психоемоційні стани у пацієнтів хоспісу.

У ході спостереження за пацієнтами волонтери відзначили такі симптоми, як: смуток, байдужість, втома, порушення сну, порушення апетиту, апатія, невпевненість у собі, почуття неадекватності, відчуття розчарування, почуття безпорадності. Ці ознаки вказують на появу депресивних явищ. Стан без депресії виявлено лише в одного пацієнта, що свідчить про стійкий психоемоційний стан. Результати оцінки рівня депресії за допомогою психологічного тестування наведено у таблиці.

\section{Таблиця. Резүльтати діагностики депресивних станів і станів, близьких до депресії, пацієнтів Волинської обласної лікарні «Хоспіс»}

\begin{tabular}{|l|c|c|c|c|}
\hline \multicolumn{1}{|c|}{ Рівень депресії } & $\begin{array}{c}\text { Стан без } \\
\text { депресії }\end{array}$ & $\begin{array}{c}\text { Легка ситуаційна депресія } \\
\text { (невротичного генезу) }\end{array}$ & $\begin{array}{c}\text { Маскована } \\
\text { депресія }\end{array}$ & $\begin{array}{c}\text { Істинний } \\
\text { депресивний стан }\end{array}$ \\
\hline $\begin{array}{l}\text { Кількість обстежених } \\
\text { осіб }\end{array}$ & 1 & 7 & 9 & 3 \\
\hline $\begin{array}{l}\text { Частка обстежених у } \\
\text { відсотках }\end{array}$ & 5 & 35 & 45 & 15 \\
\hline $\begin{array}{l}\text { Середній по групі } \\
\text { рівень депресії у балах }\end{array}$ & 45,0 & 53,9 & 68,7 & 71,3 \\
\hline
\end{tabular}

у результаті дослідження виявлено, що у вибірці переважає субдепресивний стан або маскована депресія - $45 \%$, рівень легкої депресії відзначають у 35 \% опитаних. Істинно депресивний стан спостерігають у $15 \%$ пацієнтів. Стан без депресії становить $5 \%$. Отже, у пацієнтів, які спілкуються із волонтерами і отримують хоспісну допомогу, переважають легкі форми депресивних розладів.

Варто звернути увагу на варіанти маскованої депресії, яка в даному випадку спостерігається найчастіше. Депресія має місце під маскою різноманітної соматовегетативної симптоматики, а прояви депресії можуть бути нетиповими.

Під час першого огляду хворих із маскованою депресією складаеться враження, що психомоторна загальмованість у них відсутня (ознака в тому чи іншому ступені властива для будь-якої форми депресії). Такі хворі, як прави- ло, багатомовні, часто самостійно звертаються до лікарів, дещо нав'язливі в своїх скаргах, до того ж їм особливо часто здається, що їх недостатньо добре зрозуміли, не хочуть вислуховувати. Хворі схильні до деталізації переживань, вкрай іпохондричні, емоційно-лабільні, занепокоєні можливою динамікою розвитку захворювання [4].

Будь-яка хвора людина потребуе особливої, підвищеної уваги й турботи. Людина ж, яка зазнає сильного болю і душевних страждань від усвідомлення близької смерті, стае занадто сприйнятливою та вразливою, може виявляти роздратування або злість. Біль може повністю знищити людину як особистість. Він завдає нестерпні страждання хворому й нерідко деформує його психіку. Тому, надаючи допомогу для полегшення фізичного стану паліативним паціентам, необхідно звертати особливу увагу на 
психологічну реакцію пацієнта на свій стан. Волонтер має вміти виявити і враховувати ці особливості хворого при спілкуванні і наданні допомоги.

Психологічний стрес від наявності невиліковного захворювання, особисті й соціальні проблеми при наявності у хворих психічних порушень надзвичайно ускладнюють їхне життя. Поряд із проблемами соціальної ізоляції не менш значимими в плані формування реактивних психічних розладів є й проблеми, пов'язані з невиліковною хворобою, що розвивається, і тривалістю життя, що залишилося. Працюючи 3 такими пацієнтами, студенти-волонтери роблять усе можливе для того, щоб покращити якість життя паціента із депресивними станами. Здійснюють догляд, допомагають іти на прогулянку, читають художню та релігійну літературу, розповідають суспільні та соціальні новини.

Психологічною проблемою, з якою стикаються хворі, є їхня соціальна ізоляція [5]. У них зменшується кількість спілкування із сім'єю, трапляються випадки, коли від них відмовляються родичі й друзі. Навіть у хоспісі паціенти можуть відчувати «стіну» між собою й зовнішнім світом. На нашу думку, доцільно навчати волонтерів навичок активного слухання, стилю спілкування, який характеризується як центрований підхід до пацієнтів.

Традиційно вважалося, що паліативна допомога починається виключно з того моменту, коли стає очевидно, що смерть хворого неминуча. Зараз прийнято вважати, що паліативна допомога повинна починатися на більш ранніх стадіях захворювання, що прогресує. Вона використовує всі медичні втручання, які є в їі арсеналі, серед них $є$ і засоби, спрямовані на боротьбу із захворюванням, заходи психологічної підтримки паціента та його родини, соціальна опіка.

Отже, зміст і характер діяльності волонтерів мають цілий комплекс складних медичних, соціальних, духовно-етичних і організаційних проб-

\section{ЛITEPATУРА}

1. Марута Н. А. Депрессиив общемедицинской практике справ : пособие для врачейпервичной медико-санитарной сети / Н. А. Марута, Л. Н. Юрьева, А. И. Мамчур. - К., 2009. - 30 с.

2. Смулевич А. Б. Депрессиипри соматическихипсихических заболеваниях / А. Б. Смулевич. - М. : Медицинское информационное агентство, 2003. - 432 с.

3. Практические занятия по психологии / под ред. А. Ц. Пуни. - М. : ФиС, 1977.- 384 с. лем. Тому організація такої системи підтримки пацієнта вимагає обов'язкової попередньої ґрунтовної підготовки майбутніх добровольців, відсутність якої - одна з основних причин нечисленності хоспісного волонтерського руху. Одним із шляхів залучення до волонтерства $€$ створення науково-педагогічних умов для забезпечення ефективної співпраці медичного коледжу та хоспісу. Зокрема, важливим етапом підготовки волонтерів є формування у них комунікативних навичок і здатності адекватно розуміти психологічний стан паціента.

Висновки. У пацієнтів, які спілкуються із волонтерами і отримують хоспісну допомогу, переважають легкі і скриті форми депресивних розладів. Ознаки депресії виявлені не у всіх пацієнтів. Отже, вважаємо роботу волонтерів як одну із складових хоспісної допомоги, доцільною, ії потрібно розвивати.

Психологічна освіта є одним із важливих завдань підготовки середніх медичних працівників. Наявність невиліковного захворювання для багатьох хворих є психотравмуючою ситуацією. Реакція на хворобу проявляеться по-різному і залежить не тільки від інтенсивності загрози життю, складності захворювань, індивідуальнопсихологічних характеристик. Тяжкохворим потрібен особливий догляд та увага. Досить частими $є$ раптові погіршання стану здоров'я, тому при наданні догляду важливо вміти оцінити психологічний стан пацієнта у процесі спілкування.

Підготовка волонтерів має бути спрямована на формування комунікативних навичок і засвоєння елементів підходу, центрованого на проблемах пацієнта, що сприятиме психологічній підтримці та покращить фізичну опіку, незалежно від стадії хвороби й можливого ії результату.

У подальшому доцільно удосконалювати навчальні програми для студентів медичних коледжей, включаючи до практичних завдань комплекти ситуаційних задач та ділових ігор.

4. ПилягинаГ. Я. Психические расстройства в общетерапевтической практике / Г. Я. Пилягина / / Doctor. 2002. - № 6. - С. 17-21.

5. Овсяннікова Я. О. Самооцінка та самотність: залежність і взаємозв'язок / Я. О. Овсяннікова, Т. Ю. Довбій / / Психологічні науки. - 2011. - № 58. C. 119-122. 